\title{
Comparative Bioequivalence Studies of doxysam and doxycycline (Pfizer) by reversed phase HPLC.
}

\author{
Nagham Abdulraheem Jasim * $\quad$ Fahdil M Abid * \\ Waleed A. Mahmoud $* *$
}

Date of acceptance $1 / 3 / 2010$

\begin{abstract}
:
Isocratic high performance liquid chromatography on reversed phase a (150x 4.6 mm I.D), $5 \mu \mathrm{m} \mu$-Bondapak RP-8 column (with acidic mobile phase allow the separation of doxcycycline hydrochloride with low detection limit of $0.2 \mu \mathrm{g} / \mathrm{ml}$ detected by UV set at $226 \mathrm{~nm}$. The method was validated for Doxycycline between $0.156-$ to $5 \mu \mathrm{g} / \mathrm{ml}$. The concentration of doxycycline was assessed in two single dose randomized crossover studies with intervals of one week between two period. In sera of 20 adults healthy male volunteers with average age of $(42 \pm 10)$ year, body weight $48-85 \mathrm{~kg}$, body height of $(160-185 \mathrm{~cm})$ after a single dose of doxycycline hydrochoride $100 \mathrm{mg}$ in form of capsules were orally administrated for both formulations. The blood samples $(2 \mathrm{ml})$ were drawn concomitantly from $0.5-24$ hours. $\mu \mathrm{g}$

The pharmacokinetics parameter were obtained from the mean serum concentration measured at various sampling times for both formulations. The maximum peak concentration $\left(\mathrm{C}_{\max }\right)$ of doxycycline reference drug from Pfizer In serum was $(3.1 \pm 0.094 \mu \mathrm{g} / \mathrm{ml})$ attained in $2 \mathrm{hrs}$. While the maximum concentration $\left(\mathrm{C}_{\text {max }}\right)$ of test drug doxysam $(2.8 \pm 0.098 \mu \mathrm{g} / \mathrm{ml})$ attained in about $2 \mathrm{hrs}$, both drug have long elimination time with half time of approximately ( $13 \mathrm{hrs}$.) Both test and reference drug were show no significant difference in pharmacokinetics parameters, so they were considered to be bioequivalent.
\end{abstract}

Key word: Bioequivalence of two doxycycline, pharmacokinetics, HPLC.

\section{Introduction}

Doxycycline is a semi-synthetic tetracycline invented and clinically developed in the early 1960s (1), This semi-synthetic tetracycline is manufactured from oxytetracycline in five chemical steps. Clinically, doxycycline is shown to be much more active than tetracycline and its therapeutical value continues to be recognized for treatment of various inflammation.(2).

Doxycycline is commonly used in pharmaceutical formulations under two chemical forms: the monohydrate form and the hyclate form. The monohydrate is the base molecule hydrated with one

molecule of water and is used in the formulation of capsules and, in some markets, powder oral suspensions to be reconstituted with water). The hyclate is a hydrochloric acid salt solvated with water and ethanol and is used in the formulation of capsules or tablets. The structural formula presented in fig. 1.

\footnotetext{
*Ministry of science and technology, Chemical Research Center

**College of Science for Women / Baghdad University
} 


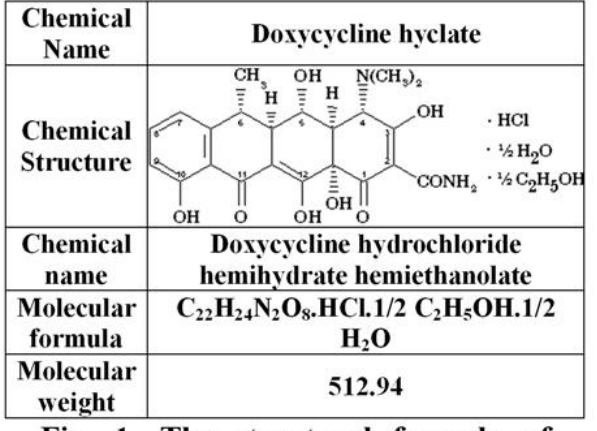

Fig. 1. The structural formula of doxysam.

A high-performance liquid chromatographic (HPLC) method for the determination of lipoplilic doxycycline in plasma has been described by Sharma and co-workers (3). Maximum resolution on reversed phase columns can be achieved with acidic eluents when their $\mathrm{pH}$ is below the isoelectric point of the tetracycline (ca. $\mathrm{pH}$ 5-4,5). We have developed a single-step extraction method with subsequent chromatographic analysis on RP-8 material. However the rate of recovery of doxycycline varies when different batches of column packing material are used. This difficulty can be overcome and the reproducibility of the results can be sufficiently enhanced by (1) preequilibration of the column with a compound more lipophilic than doxycycline or any other tetracycline to be analyzed; and (2) use of a final eluent less polar than the equilibration eluent.

\section{Materials and Methods \\ Chromatographic apparatus}

A Shimadzu 10 AVP (Japan)

analytical chromatography equipped with a (150x $4.6 \mathrm{~mm}$ I.D), $5 \mu \mathrm{m} \mu-$ Bondapak RP-8 column (water Assoc.) was fitted with Shimadzu UV Detector using low- dead volume hardware. A mobile phase of acetonitric $-0.01 \mathrm{M} \quad \mathrm{NaH}_{2} \mathrm{PO}_{4}$ in water adjusted to $\mathrm{pH} 2.4$ with diluted nitric acid (30:70, v/v) was filtered, degassed and used. The range of detector was fixed at 0.02 a.u.f.s ,The analysis carried out with chromatopack CR-8A, which has ability to draw and calculate the peak area and Peak high simultaneously were used throughout this work The concentration of doxycycline were calculated by comparison the peak area of standard with that of authentic standard under the same separated conditions.

\section{Chemicals}

All chemicals used were of analytical grade. Pure doxycycline standard was a gift from SDI /Sammaria. Doxycycline capsules from Pfizer and doxasam from SDI were used as obtained from the suppliers. Acetonitrile HPLC grade from (Merck, U.S.A), all mobile phase were filltered and degassed by purging the eluent for 5 minutes with stream of helium.

The chromatographic analysis of doxycycline was performed with eluent II $\left(0.01 \mathrm{M} \mathrm{NaH}_{2} \mathrm{PO}_{4}\right.$ in wateracetonitrile, $73: 27 ; \mathrm{pH} \mathrm{2.4),} \mathrm{the} \mathrm{UV}$ absorption being measured at $226 \mathrm{~nm}$.

\section{Preparation of serum samples}

Blood samples $(2 \mathrm{ml})$ was collected in 10-ml glass test tube before and after drug administration of both formula in crossover study at time interval of, $0.5,1,2,3,4,5,6,8,10$, 12,18 , and $24 \mathrm{hrs}$. A $200-\mu \mathrm{l}$ volume of serum was mixed with $200 \mu \mathrm{l} 0.03$ M $\mathrm{H}_{3} \mathrm{PO}_{4}$; after 15 min $1 \mathrm{ml}$ acetonitrile-buffer $\left(0.01 \mathrm{M} \mathrm{NaH}_{2} \mathrm{PO}_{4}\right.$, $\mathrm{pH} 2.4)(50: 50) \quad$ was added $5 \mathrm{~min}$ later, most of the precipitated proteins were removed by centrifuged at (2000rpm $5 \mathrm{~min}$ ) and the supernatant taken for the HPLC analysis or frozen at $-20^{\circ} \mathrm{C}$ until taken for assy.

\section{Spiked serum}

Accuracy and precision of the analytical method were studied by 
spiking drug-free serum with doxycycline dissolved in $0.01 \mathrm{M}$ phosphoric acid to give final concentration of $0.5,1,5$, and 10 $\mu \mathrm{g} / \mathrm{ml}$.after incubation at $37{ }^{\circ} \mathrm{C}$ for 30 minutes; doxycycline was extracted as described above.

\section{Recovery}

For recovery experiments, doxycycline dissolved in $0.01 \mathrm{M}$ phosphoric acid was added to serum to give a final concentration of $0.5,1,5$, and $10 \mu \mathrm{g} / \mathrm{ml}$. After incubation at $37^{\circ}$ for $30 \mathrm{~min}$, doxycycline was extracted as described above. The recovery of doxycycline in serum were between $83 \%$ at concentration below $1 \mu \mathrm{g} / \mathrm{ml}$ and $96.5 \%$ for concentation $10 \mu \mathrm{g} / \mathrm{ml}$ as shown in table 1 .

Table 1. Recovery and precision of doxycycline.

\begin{tabular}{|c|c|c|}
\hline sample & $\begin{array}{c}\text { Drug added } \\
\mathrm{mcg} / \mathrm{ml}\end{array}$ & Recovery \% \\
\hline $\begin{array}{c}\text { Spiked } \\
\text { serum }\end{array}$ & 0.5 & $83.2 \pm 8.7$ \\
\hline & 1 & $92.2 \pm 3.2$ \\
\cline { 2 - 3 } & 5 & $94.3 \pm 3.8$ \\
\cline { 2 - 3 } & 10 & $96.5 \pm 2.8$ \\
\hline
\end{tabular}

\section{Results and Discussion}

High ionic strength of the eluent or an unconditioned column resut in tailing of the eluted compound. When the column is conditioned with the lipophilic anhydrotetracycline, an eluent with relatively low content of acetonitrile $(27 \%)$ elutes doxycycline standard within $6.2 \mathrm{~min}$. Doxycycline extracted from serum samples has the same retention time of $3.9 \mathrm{~min}$ as doxycycline standards dissolved either in eluent or in $0.1 \mathrm{M}$ phosphoric acid. The recovery of doxycycline from serum is $(83.2 \pm 8.7, \mathrm{n}=10)$, when the doxycycline concentrations are not higher than $0.5 \mu \mathrm{g} / \mathrm{ml}$. At a concentration of $10 \mu \mathrm{g} / \mathrm{ml}$ the recovery from serum is about $97.6 \%$. This may be due to a partial precipitation of doxycycline together with some proteins, as described for tetracycline ( 5 ).

\section{Pharmacokinetic properties}

- Doxycycline is administered orally (capsules) and is rapidly and almost completely ( $83 \%$ to $97 \%$ ) absorbed from the gastrointestinal tract and then distributed throughout body tissues. The absorption half-life lasts about 50 minutes. Serum peak levels are achieved after 2 hours and the serum half-life lasts between $(14-22)$ hours. It was reported (6) that interference by food with the absorption of doxycycline is not significant and, therefore, does not cause reduction of the serum levels below the minimum inhibitory concentration (about $0.8 \mu \mathrm{g} / \mathrm{ml}$ ).

Doxycycline is widely distributed throughout body tissues. The concentrations of doxycycline in serum were between $(0.5-3 \mu \mathrm{g} / \mathrm{ml})$. Since the minimum effective concentration of doxycycline is $0.8 \mu \mathrm{g}$ $/ \mathrm{ml}$ (7), so this pharmacokinetic profile allows for a once-daily oral therapy, which is of importance for patient compliance particularly in chronic treatment involving a multidrug regimen.

Doxycycline does not accumulate in the body of patients with renal impairment and hemodialysis does not affect the serum half-life (it does not remove doxycycline from the blood to any great extent). Doxycycline is not metabolized in a measurable extent in the human body (8).

\section{Excretion}

Doxycycline is eliminated through the intestinal tract and in the urine (about $40 \%$ in $72 \mathrm{~h}$ ). It presents in a biologically inactive form in the feces. Consequently, it does not affect the 
intestinal flora and is therefore less likely to cause diarrhea.

Doxycycline is recommended for the treatment of acute exacerbations of chronic bronchitis caused by Haemophillus influenza or Pneumococcus pneumonia.

Doxycycline is considered to be the ideal choice for a typical pneumonia because of its activity against all of the possible pathogens responsible for the disease.

It is reported that Doxycycline shows a favorable response in soft tissue infections because of its superior penetration associated with its relatively high lipid solubility (9).

Doxycycline is indicated in the oral treatment of acute traumatic ulcers, cellulitis and abscess. Good clinical response is also obtained in the oral treatment of soft tissue infections like perirectal abscess, cellulitis, gangrene and pedal or other superficial abscesses.

The mean serum concentration of doxycycline at various interval time (0.5-24 hrs) were measured for both formulations, the average results were tabulated in table (2), while the serum concentration-time curve for both formulations after oral administraion of $250 \mathrm{mg}$ capsules were constructed as shown in fig( 2). The pharmacokinetics parameter for reference drug of doxycycline from Pfizer and test doxysam from SDI were calculated as swhon in table (3). The pharamacokinetics parameters show no significant difference between both reference and tes formula.

Table 2: Average serum concentrations of deoxycycline (Pfizer) in $\mathrm{mcg} / \mathrm{ml}$ with time in sera of 20 health volunteers compared with deoxycycline Sammara Drugs Industry (SDI) after oral dose of $100 \mathrm{mg}$ from both formulations.

\begin{tabular}{|c|c|c|c|c|c|c|c|c|c|c|c|c|}
\hline No. & $\mathbf{0}$ & $\mathbf{0 . 5}$ & $\mathbf{1}$ & $\mathbf{2}$ & $\mathbf{3}$ & $\mathbf{4}$ & $\mathbf{6}$ & $\mathbf{8}$ & $\mathbf{1 0}$ & $\mathbf{1 2}$ & $\mathbf{1 6}$ & $\mathbf{2 4}$ \\
\hline Mean & 0 & 0.91 & 1.82 & 3.1 & 2.0 & 2.80 & 2.50 & 2.30 & 2.10 & 1.95 & 1.70 & 1.31 \\
\hline SDI & 0 & 0.054 & 0.084 & 0.091 & 0.072 & 0.068 & 0.112 & 0.12 & 0.092 & 0.089 & 0.1 & 0.12 \\
\hline & & & & & & & & & & & & \\
\hline $\begin{array}{c}\text { Mean } \\
\text { SDI }\end{array}$ & 0 & 0.804 & 1.723 & 2.80 & 2.634 & 2.444 & 2.144 & 1.95 & 1.750 & 1.599 & 1.33 & 0.96 \\
\hline \pm SD & 0 & 0.082 & 0.091 & 0.098 & 0.099 & 0.098 & 0.113 & 0.11 & 0.111 & 0.111 & 0.11 & 0.11 \\
\hline & & & & & & & & & & & & \\
\hline
\end{tabular}

Table 3: Pharmacokinetics of doxycycline (Pfizer) $100 \mathrm{mg}$ capsules and SDI 100

\begin{tabular}{|c|c|c|c|c|c|c|c|}
\hline No. & $\begin{array}{c}\mathrm{Ka} \\
\mathrm{hr}^{-1}\end{array}$ & $\begin{array}{c}\mathrm{Ka}_{0.5 \mathrm{t}} \\
\mathrm{hr}^{-1}\end{array}$ & $\begin{array}{c}\mathrm{K}_{\text {elm. }} \\
\mathrm{hr}^{-1}\end{array}$ & $\begin{array}{c}\text { Kelm. }_{.0 .5 t} \\
\mathrm{H}^{-1}\end{array}$ & $\begin{array}{c}\mathrm{C}_{\max } \\
\mu \mathrm{g} / \mathrm{ml}\end{array}$ & $\begin{array}{c}\mathrm{T}_{\max } \\
\mathrm{hr} .\end{array}$ & $\begin{array}{c}\mathrm{AUC} \\
(\mu \mathrm{g} / \mathrm{ml}) \mathrm{hr}\end{array}$ \\
\hline $\begin{array}{c}\text { Mean } \\
\text { pfizer }\end{array}$ & 1.499 & 0.463 & 0.062 & 16.357 & 3.055 & 2 & 44.82 \\
\hline \pm SD & 0.124 & 0.038 & 0.007 & 2.095 & 0.098 & 0 & 2.71 \\
\hline & & & & & & & \\
\hline $\begin{array}{c}\text { Mean } \\
\text { SDI }\end{array}$ & 1.534 & 0.451 & 0.071 & 13.638 & 2.835 & 2 & 44.252 \\
\hline$\underline{ \pm S D}$ & 0.114 & 0.029 & 0.011 & 3.903 & 0.098 & 0 & 1.893 \\
\hline
\end{tabular}




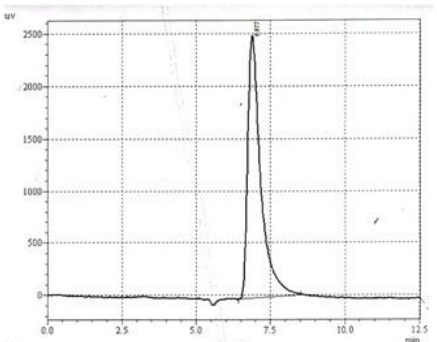

(a) Standard

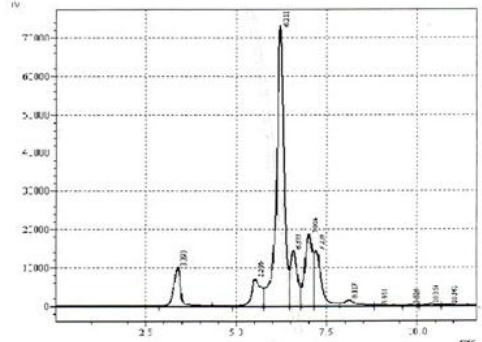

(b)Sample

Fig (2) Separation of Doxycycline on reversed phase $(150 \times 4.6 \mathrm{~mm}$ id) Column, mobile phase of acetontrile : $0.01 \mathrm{M}$ Sodium Phosphate $0.01 \mathrm{M}$

$(30: 70 \mathrm{v} / \mathrm{v})$ Detection UV Set at $220 \mathrm{~nm}$. Flow rate $1 \mathrm{ml} / \mathrm{min}$, Temp $30 \mathrm{C}^{\circ}$.

a) Standard.

b) Sample.

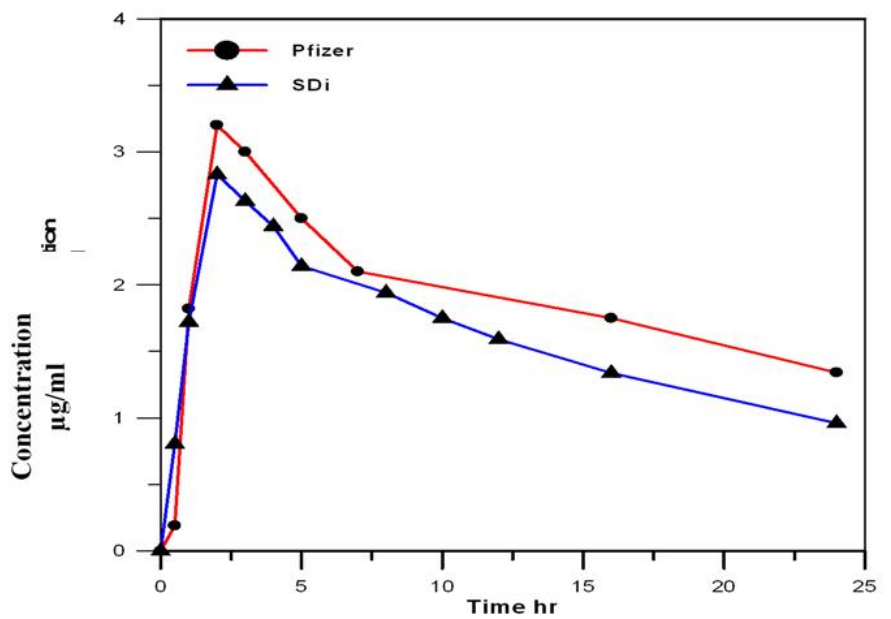

Fig:2 Time concentration Curve for tow drug formulation Pfizer as reference drug and SDI as Sample.

\section{References:}

1- Golub L.M., Sorsa T., Lee H-M., Ciancio S., Sorbi D., Ramamurthy N.S., Gruber B., Salo T., Konttinen Y.T.: Doxycycline Inhibits Neutrophil (PMN)-type Matrix Metalloproteinases in Human Adult Periodontitis Gingiva. J. Clin. Periodontol 1995; 22: 100109.

2- Golub L.M., Ciancio S., Ramamurthy N.S., Leung M., McNamara T.F.: Low dose
Doxycycline Therapy: Effect on Gingival and Crevicular Fluid Collagenase Activity in Humans. J. Periodont Res 1990; 25: 321-330.

3-J.P. Sharma, E. G. Perkins and F. R. Bevill, J. Chromatogr., 134 (1977) 441.

4- A, P. De Leenheer and H. J. C. F. Nelis, J. Chromatogr., 140 (1977) 293.

5 -R. Bocker and C.-J. Ester, Arzneim, Arzneim.-Forsch., 29 (1979) 1693. 
6-. Golub L.M., Lee H.M., Greenwald R.A., Ryan M.E., Salo T., Giannobile W.V.: A Matrix Metalloproteinase Inhibitor

Reduces Bone-type Collagen Degradation Fragments and Specific Collegenases in Gingival Crevicular luid During Adult Periodontitis. Inflammation Research 1997; 46: 310-319.

7-. Saivain S., Houin G.: Clinical Pharmacokinetics of Doxycycline and Minocycline. Clin.
Pharmacokinetics 1988; 15: 355366.

8-Schach von Wittenau M., Twomey T.: The Disposition of Doxycycline by Man and Dog. Chemotherapy 1971; 16: 217-228.

9- Campistron G., Coulais Y., Caillard C., Mosser J., Pontagnier H., Houin G.: Pharmacokinetics and Bioavailability of Doxycycline in Humans. Arzneimittel Forschung 1986; 36: 1705- 1707.

\section{دراسة مقارنة التكافؤ الحيوي لمادة دوكسي سام و دوكسي سايكلين بواسطة

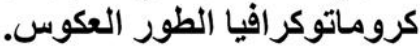

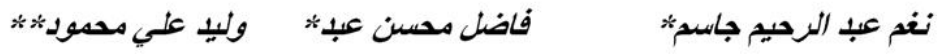 \\ * وزارة العلوم والتكنلوجيا/ مركز بحوث الكيمياء **قسم الكيمياء/ كلية العلوم للبنات/ جامعة بغداد الكراد}

طريقة الطور الثابت كروموتوكر افيا الطور العكوس، بأستخدام عمود

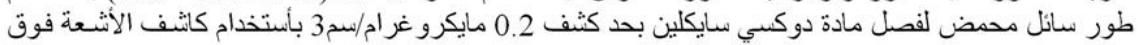

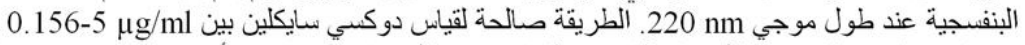

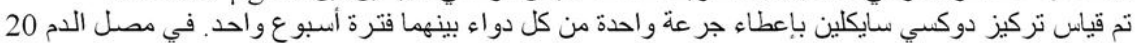

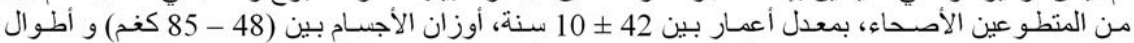

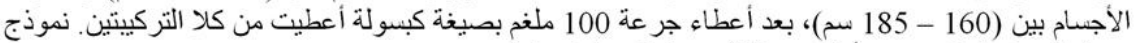

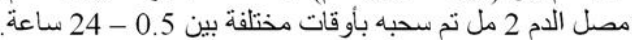

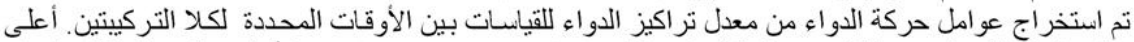

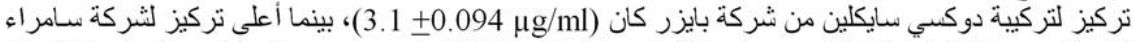

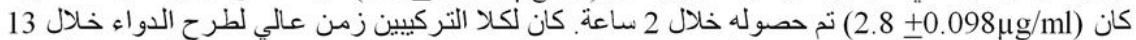

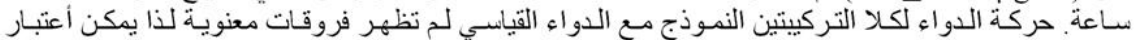
التركيبتين متكافئة 